\title{
LONG-TeRm SuRVEILLANCE PLAN For tHE BURRo CANYON Disposal Cell SLICK ROCK, ColORADO
}

March 1997

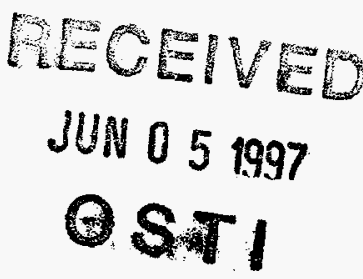

This report was prepared as an account of work sponsored by an agency of the United States Government. Neither the United States Government nor any agency thereof, nor any of their empleyees, makes any warranty, express or implied, or assumes any legal liability or responsibility for the accuracy, completeness, or usefulness of any information, apparatus, product, or process disclosed, or represents that its use would not infringe privately owned rights. Reference herein to any specific commercial product, process, or service by trade name, trademark, manufacturer, or otherwise does not necessarily constitute or imply its endorsement, recommendation, or favoring by the United States Government or any agency thereof. The views and opinions of authors expressed herein do not necessarily state or reflect those of the United States Government or any agency thereof. 


\section{DISClamier}

Portions of this document may be illegible in electronic image products. Images are produced from the best available original document. 
This report has been reproduced from the best available copy. Available in paper copy and microfiche.

Number of pages in this report: 42

DOE and DOE contractors can obtain copies of this report from:

Office of Scientific and Technical Information

P.O. Box 62

Oak Ridge, TN 37831

(615) 576-8401

This report is publicly available from:

National Technical Information Service

Department of Commerce

5285 Port Royal Road

Springfield, VA 22161

(703) 487-4650 


\title{
LONG-TERM SURVEILLANCE PLAN \\ FOR THE BURRO CANYON DISPOSAL CELL \\ SLICK ROCK, COLORADO
}

March 1997

\author{
Prepared for \\ U.S. Department of Energy \\ Environmental Restoration Division \\ UMTRA Project Team \\ Albuquerque, New Mexico \\ Prepared by \\ Jacobs Engineering Group Inc. \\ Albuquerque, New Mexico
}


Section

TABLE OF CONTENTS

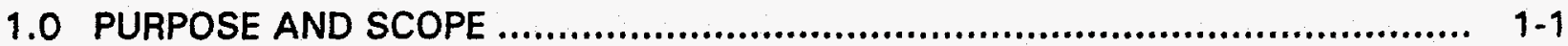

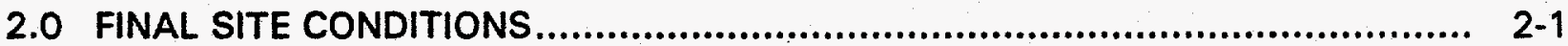

2.1 Site history ........................................................................... $2-1$

2.2 General description of the site vicinity ............................................ $2-3$

2.3 Disposal site description ............................................................ 2-3

2.3.1 Site ownership and legal description ....................................... 2-3

2.3.2 Directions to the disposal site ................................................ 2-4

2.3.3 Description of surface conditions........................................... 2-4

2.3.4 Permanent site-surveillance features....................................... 2.6

2.4 Disposal cell design.................................................................... 2-8

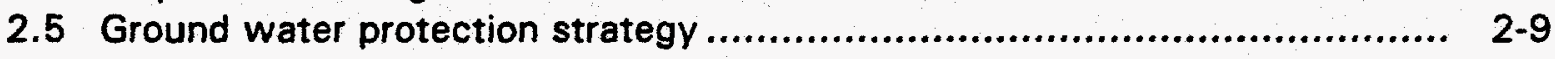

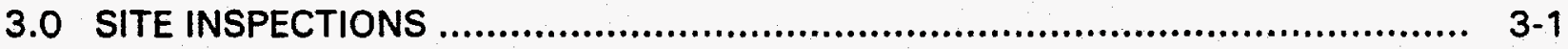

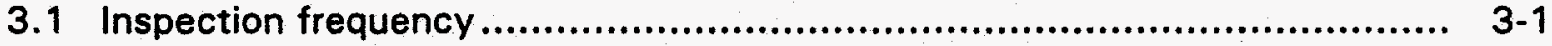

3.2 Inspection team .................................................................. $3-1$

3.3 Annual inspection ................................................................... 3-1

3.4 Follow-up inspections .............................................................. $3-3$

3.5 Quality assurance ............................................................... $3-4$

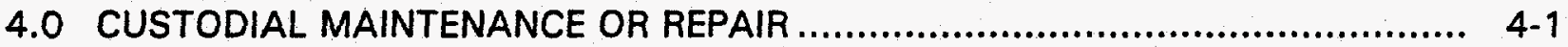

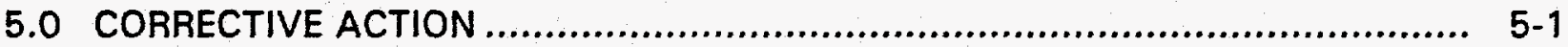

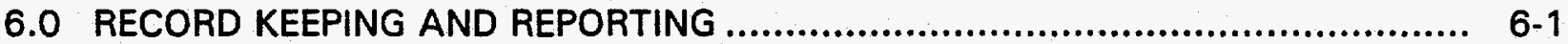

6.1 Permanent site file .................................................................. $6-1$

6.2 Inspection reports/annual reports ................................................ $6-1$

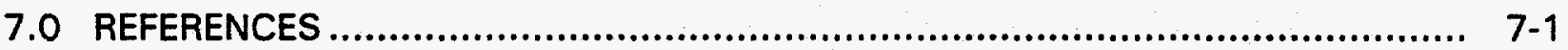

ATTACHMENT 1 NRC CONCURRENCE DOCUMENTATION

ATTACHMENT 2 SITE REAL ESTATE INFORMATION

ATTACHMENT 3 AGENCY NOTIFICATION AGREEMENTS 


\section{LIST OF FIGURES}

Figure

Page

2.1 Regional map showing locations of the North Continent, Union Carbide, and Burro Canyon sites near Slick Rock, Colorado.

2.2 Locations of processing and disposal sites, Slick Rock, Colorado...

3.1 Steps for follow-up inspections, custodial maintenance, and corrective action,

Burro Canyon, Colorado, disposal site

\section{LIST OF PLATES}

Plate 1 to be provided when received.

\section{LIST OF TABLES}

Table

2.1 Locations of permanent surveillance features, Slick Rock, Colorado, disposal site 


\section{LIST OF ACRONYMS}

$\begin{array}{ll}\text { Acronym } & \text { Definition } \\ \text { BLM } & \text { Bureau of Land Management } \\ \text { DOE } & \text { U.S. Department of Energy } \\ \text { DOI } & \text { U.S. Department of the Interior } \\ \text { EPA } & \text { U.S. Environmental Protection Agency } \\ \text { LTSP } & \text { long-term surveillance plan } \\ \text { NGVD } & \text { National Geodetic Vertical Datum } \\ \text { NRC } & \text { U.S. Nuclear Regulatory Commission } \\ \text { PLO } & \text { public land order } \\ \text { POC } & \text { point of compliance } \\ \text { QA } & \text { quality assurance } \\ \text { RAP } & \text { remedial action plan } \\ \text { UMTRA } & \text { Uranium Mill Tailings Remedial Action } \\ \text { UMTRCA } & \text { Uranium Mill Tailings Radiation Control Act }\end{array}$




\section{CHANGE HISTORY}

\begin{tabular}{|c|c|c|}
\hline Document version & Date & Pages/comments \\
\hline Rev. 0, Ver. 1 & $11 / 1 / 96$ & Initial version. \\
\hline \multirow[t]{2}{*}{ Rev. 0, Ver.-1 } & $3 / 10 / 97$ & $\begin{array}{l}\text { Response to DOE comments. } \\
\text { Revision number changed to reflect } \\
\text { delivery to NRC (Rev. } 0 \text { is initial } \\
\text { version prepared for DOE review; } \\
\text { revision number changes only on } \\
\text { return from } N R C \text { ). Version number } \\
\text { tracks internal review process (i.e., } \\
\text { return from DOE). }\end{array}$ \\
\hline & & $\begin{array}{l}\text { Internal TAC version changes } \\
\text { indicated by "-x" (e.g., } 1-1,1-2) \text {. } \\
\text { Example: Rev. } 1 \text {, Ver } 1-1 \text { shows } \\
\text { first return from NRC, first return } \\
\text { from DOE, and first TAC internal } \\
\text { review. }\end{array}$ \\
\hline
\end{tabular}




\subsection{PURPOSE AND SCOPE}

This long-term surveillance plan (LTSP) describes the U.S. Department of Energy (DOE) long-term care program for the Uranium Mill Tailings Remedial Action (UMTRA) Project Burro Canyon disposal cell in San Miguel County, Colorado.

The U.S. Nuclear Regulatory Commission (NRC) developed regulations for the issuance of a general license for the custody and long-term care of UMTRA Project disposal sites in 10 CFR Part 40. The purpose of this general license is to ensure that the UMTRA Project disposal sites are cared for in a manner that protects the public health and safety and the environment. Before each disposal site is licensed, the NRC requires the DOE to submit a site-specific LTSP. The DOE prepared this LTSP to meet this requirement for the Burro Canyon disposal cell. The general license becomes effective when the NRC concurs with the DOE's determination that remedial action is complete at the Burro Canyon disposal cell and the NRC formally accepts this LTSP. Attachment 1 contains the concurrence letters from NRC.

This LTSP describes the long-term surveillance program the DOE has implemented to ensure that the Burro Canyon disposal cell performs as designed. The program is based on site inspections to identify threats to disposal cell integrity. Ground water monitoring will not be required at the Burro Canyon disposal cell because the ground water protection strategy is supplemental standards based on low yield from the uppermost aquifer. The LTSP is based on the UMTRA Project's long-term surveillance program guidance (DOE, $1996 \mathrm{a})$ and meets the requirements of 10 CFR $\$ 40.27(\mathrm{~b})$ and 40 CFR $\$ 192.03$. 


\subsection{FINAL SITE CONDITIONS}

Remedial action at the two former uranium processing sites in Slick Rock, Colorado, consisted of excavating and relocating the residual radioactive materials to the Burro Canyon disposal cell. The DOE constructed a disposal cell to control this residual radioactive material in accordance with 40 CFR Part 192. The Burro Canyon disposal site is fenced and its perimeter is marked with warning signs. The site completion report contains a detailed description of the final site conditions (MK-F, 1997).

\subsection{SITE HISTORY}

The Burro Canyon disposal cell is approximately 5 miles (mi) ( 8 kilometers $[\mathrm{km}]$ ) by road northeast of the Slick Rock post office. It contains the tailings and mill debris from the two Slick Rock UMTRA Project processing sites 11 to 3 miles (mi) $(1.6$ to $4.8 \mathrm{~km})$ northwest of the small community of Slick Rock in San Miguel County, Colorado (Figure 2.1).

Both processing sites are on the banks of the Dolores River. The North Continent mill was designed to extract vanadium and radium salts from locally mined ores. From 1931 until 1942, vanadium was extracted from ore by a sulfuric acid leaching process. In 1942, the extraction techniques included an initial salt-roast circuit with an acid-leach process to recover vanadium, uranium, and radium concentrates (Merritt, 1971). The tailings and milling wastes were then disposed of on the alluvial floodplain below the mill. The North Continent site produced approximately 28,700 cubic yards $\left(\mathrm{yd}^{3}\right)(21,950$ cubic meters $\left.\left[\mathrm{m}^{3}\right]\right)$ of tailings. An additional $80,000 \mathrm{yd}^{3}\left(61,000 \mathrm{~m}^{3}\right)$ of contaminated materials were onsite prior to remediation.

The Union Carbide mill began operation in 1957 using a uranium-vanadium upgrading technique to process ore mined from the surrounding area. The milling process at the Union Carbide site included an initial step to dry-grind the coarse-grain sandstone, separating the fines from the coarser ore. The coarse ore fraction then was combined with a recirculated sulfuric acid solution.

Following this step, a sand-slime separation process produced a second uranium product. The sand product was further acid-leached, washed, and discharged to the tailings pile. A third uranium product resulted from an ammonia neutralization step on part of the pregnant solution. All three products comprised the upgraded material, which was shipped to the Umetco mill at Rifle, Colorado, for further processing. Due to the process of separating the finer fraction for shipment offsite, the tailings pile at the Union Carbide site is composed of fine-grained sand with virtually no slimes. The Union Carbide mill closed in December 1961 (Merritt, 1971). The quantity of tailings produced at the Union Carbide site was approximately $278,300 \mathrm{yd}^{3}\left(212,800 \mathrm{~m}^{3}\right)$. 

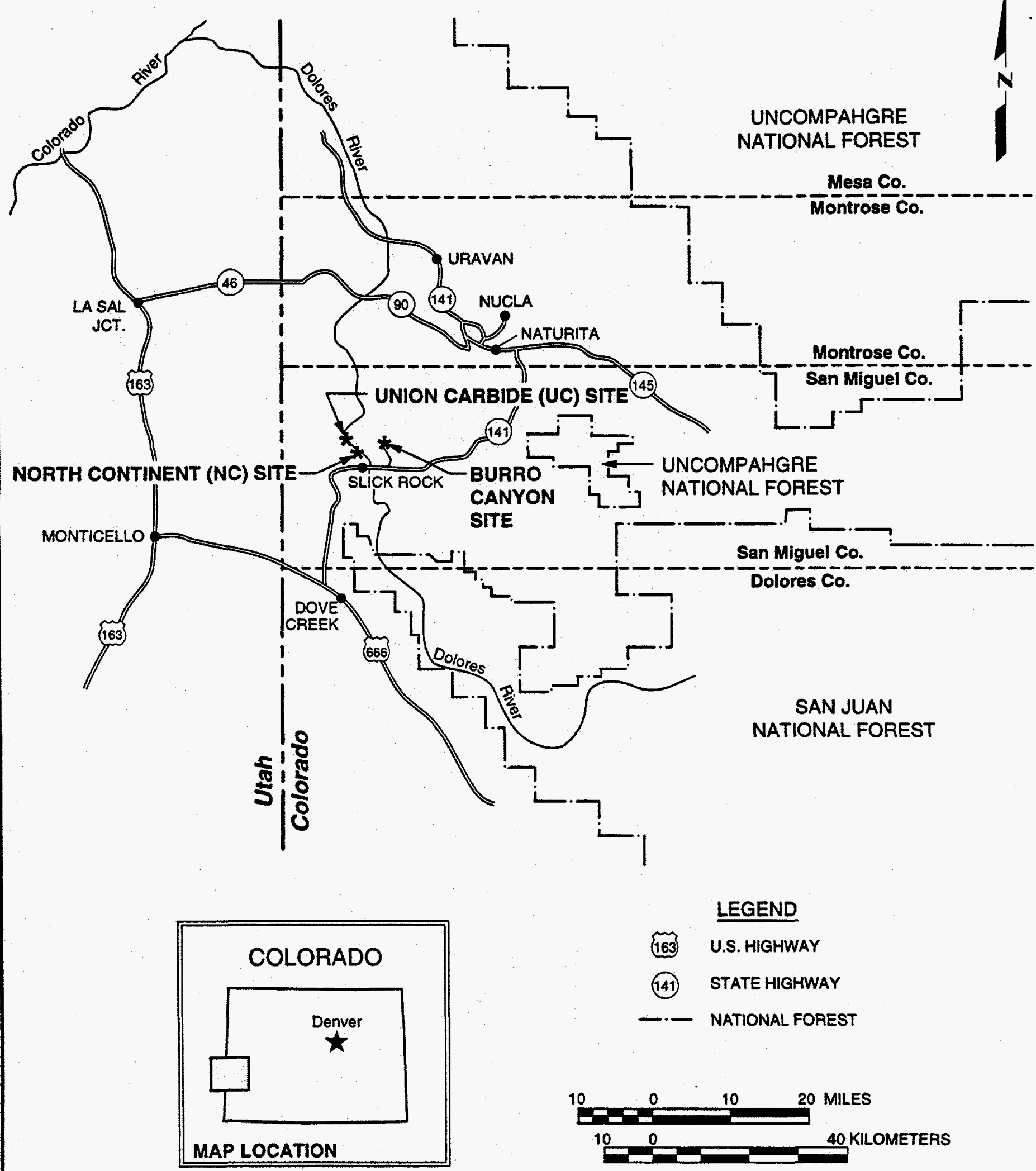

FIGURE 2.1

REGIONAL MAP SHOWING

LOCATIONS OF THE NORTH CONTINENT, UNION CARBIDE, AND BURRO CANYON SITES NEAR SLICK ROCK, COLORADO 
An additional $522,500 \mathrm{yd}^{3}\left(407,900 \mathrm{~m}^{3}\right)$ of contaminated materials were onsite prior to remediation.

Surface remedial action began in April 1995 and ended in December 1996. During 1995 and 1996, the DOE relocated uranium mill tailings and other residual radioactive materials (such as contaminated demolition debris, soils, and vicinity property materials) and placed them in the disposal cell. Disposal cell construction was completed in December 1996 with placement of a radon/infiltration barrier and frost- and erosion-protection layers. The total quantity Approximately $637,000 \mathrm{yd}^{3}\left(487,050 \mathrm{~m}^{3}\right)$ of contaminated material were placed in the disposal cell. Approximately $163,000 \mathrm{yd}^{3}\left(124,630 \mathrm{~m}^{3}\right)$ of uncontaminated material were placed in the cell.

The Uranium Mill Tailings Radiation Control Act (UMTRCA) of 1978 gave the DOE authority to perform remedial action at the Slick Rock processing sites 142 USC $\$ 7901$ et seq.). The DOE evaluated the environmental impacts associated with the remedial action in an environmental assessment (DOE, 1995). The NRC and the state of Colorado concurred with the DOE's remedial action plan (RAP) (DOE, 1996b) to comply with the requirements of 40 CFR Part 192, Subparts $A$ through $C$.

The DOE prepared a completion report documenting compliance with the remedial action plan and the site as-built conditions (MK-F, 1997). The DOE also prepared a final audit report and certification summary and submitted it and the completion report to the NRC for concurrence. NRC concurrence on the certification report is included in the permanent site file.

\subsection{GENERAL DESCRIPTION OF THE SITE VICINITY}

The population of San Miguel County is approximately 4314 (DOC, 1991). The Slick Rock area is sparsely populated; 10 people live within $10 \mathrm{mi}(1.6 \mathrm{~km})$ of the sites. The dominant land use in the area is livestock grazing. Historically, mining was common and the area contains numerous abandoned mines and mining roads.

\section{$2.3 \quad$ DISPOSAL SITE DESCRIPTION}

This section briefly describes the Burro Canyon disposal cell. Detailed descriptions can be found in the site RAP (DOE, 1996b) and completion report (MK-F, 1997).

\subsubsection{Site ownership and legal description}

The Burro Canyon disposal site is located on U.S. Bureau of Land Management (BLM)-administered land. Ranchers use the area for cattle grazing approximately 7 months of the year. The surrounding area is public land administered by the BLM, and is used primarily for grazing, hunting, and other recreational uses, with occasional mineral development as market conditions warrant. Attachment 2 provides a legal description of the disposal site. Plate 1 shows the final site 
boundary and identifies site ownership and the surrounding areas at the time of licensing.

\subsubsection{Directions to the disposal site}

The Burro Canyon disposal site can be reached by automobile via paved and graded dirt roads (Figure 2.2 ) by following these directions:

1. From Slick Rock take State Highway 141 east approximately $5 \mathrm{mi}(8 \mathrm{~km})$.

2. Turn left (north) onto the site access road. Travel approximately $0.75 \mathrm{mi}$ $(1.2 \mathrm{~km})$ to the site. The site access point is marked by an entrance sign and a granite site marker located just inside the site fence.

Entry to the disposal site is restricted by a barbed-wire fence around the site perimeter. The south access gate is kept locked; the key needed to enter the site may be obtained from the DOE Grand Junction Office.

\subsubsection{Description of surface conditions}

The Burro Canyon disposal site is located on approximately 62 acres (ac) 125 hectares [ha]) of land (Plate 1). The completion report (MK-F, 1997) contains a detailed description of final site conditions, including the results of the final site topographic survey. The site is enclosed with a five-strand, smooth-wire fence that was placed during construction. The exclusion boundary is marked with warning signs, boundary markers, and survey monuments. The tailings and other contaminated materials are contained in a rock-covered disposal cell located in the center of the site.

During final site grading, all areas were contoured to promote drainage away from the disposal cell. The DOE used a mixture of grass species to revegetate all disturbed areas of the disposal site not covered by riprap (MK-ECE, 1996).

At the completion of remedial action, the DOE documented final disposal site conditions with site maps, as-built drawings, and ground and aerial photographs (MK-F, 1997). This documentation illustrates baseline conditions for comparison to future disposal site conditions. Lithologic logs and construction data for monitor wells drilled on and around the disposal site provide detailed site hydrogeology data. All original drawings, site maps, well logs, and photographs are maintained in the Slick Rock permanent site file. 


\subsubsection{Permanent site-surveillance features}

Survey and boundary monuments, site markers, and warning signs are the permanent, long-term surveillance features of the Burro Canyon disposal cell. Plate 1 shows the locations of these features. Table 2.1 provides their survey grid coordinates. Typical construction and installation specifications for these features are shown in the long-term surveillance guidance (DOE, 1996a) and subcontract documents (MK-ECE, 1996).

Three survey monuments establish permanent horizontal control based on the Colorado State Plane Coordinate System (Central Zone) and are referenced to the Project Survey Control Point, which is located about 700 feet $(\mathrm{ft})(210$ meters [m]) east of the southeast corner of the site at an elevation of 7923.32 $\mathrm{ft}(2415.03 \mathrm{~m})$ above National Geodetic Vertical Datum (NGVD). The three permanent survey monuments (PM-1, PM-2, and PM-3) are Berntsen RT-1 markers set in concrete with the monument approximately 4 inches (in) (centimeters [cm]) above ground level. Magnets in the markers will permit easier detection if they become buried over time. The survey monument identification number is stamped on the top of the metal cap.

Five boundary monuments lie along the final site boundary. These monuments are Berntsen Model A-1 survey monuments set in concrete with the monument approximately 1 inch (25 millimeter [mm]) above ground level. Magnets in the A-1 monuments will allow easier detection if they become buried. The boundary monument identification number is stamped on the top of the metal cap.

Two unpolished granite markers with an incised message identify the Burro Canyon disposal cell. The message includes a drawing showing the general location of the stabilized disposal cell within the site boundaries, the date of closure, the weight of tailings $(1,140,000$ dry tons $[1,034,000$ metric tons $])$, and the amount of radioactivity (175 curies of radium-226). Site marker SMK-1, near the south site access gate, is set in reinforced concrete that extends $3 \mathrm{ft}$ $(0.9 \mathrm{~m})$ below the ground surface. Site marker SMK-2, at the crest of the disposal cell, is set in reinforced concrete that extends to the top of the frostprotection barrier.

The DOE-posted warning signs (18 $\times 24$ inches $[610 \times 460 \mathrm{~mm}])$ indicate property use around the disposal site perimeter. The site entrance sign displaying the DOE 24-hour telephone number is at the south access gate near site marker SMK-1. In addition to the entrance sign, 28 perimeter warning signs are located approximately $5 \mathrm{ft}(1.5 \mathrm{~m})$ inside the site fence at approximately $200-\mathrm{ft}(60-\mathrm{m})$ intervals. The warning signs are mounted on steel posts with the tops of the signs approximately $6 \mathrm{ft}(2.0 \mathrm{~m})$ above the ground surface. The sign posts are embedded in concrete to a depth of approximately $3 \mathrm{ft}(1.0 \mathrm{~m})$ below ground surface. 
Table 2.1 Locations of permanent surveillance features, Slick Rock, Colorado, disposal site

\begin{tabular}{cc}
\hline Feature & Location coordinates \\
\hline Site markers & N 18,700; E 21,650 \\
SMK-1 & N 19,860; E 21,930 \\
Survey monuments & \\
\hline PM-1 & N 18,600; E 22,440 \\
PM-2 & N 21,370; E 19,825 \\
PM-3 & N 20,00; E 22,500 \\
Boundary monuments & \\
BM-1 & N 19,020; E 21,300 \\
BM-2 & N 20,310; E 21,300 \\
BM-3 & N 20,310; E 22,625 \\
BM-4 & N 19,360; E 22,575 \\
BM-5 & N 18,690; E 22,350
\end{tabular}

\footnotetext{
${ }^{a}$ Coordinates in feet based on Project Survey Control Point (N 15,000;
}

E 15,000 - modified Colorado State Plane Coordinate System).

From MK-ECE, 1996. 


\subsection{DISPOSAL CELL DESIGN}

The 12-ac (4.9-ha) disposal cell is located on a small mesa top isolated from upland drainage runoff. It also is located in an area that is not subject to significant hazard from slope failure processes such as landslides, debris flows, mud flows, and rock falls. The geomorphic processes posing a potential hazard to the stabilized disposal cell are ephemeral drainage channel changes, lowgradient slope erosion, and wind erosion; however, these processes are not reasonably expected to affect the disposal cell within the next 1000 years, or in any case for at least 200 years.

The disposal cell is constructed partially below grade and rises above the surrounding terrain to a maximum elevation of about $5895 \mathrm{ft}(1797 \mathrm{~m})$ above NGVD. The disposal cell contains approximately $801,105 \mathrm{yd}^{3}\left(483,200 \mathrm{~m}^{3}\right)$ of relocated tailings and other residual radioactive materials, primarily contaminated soil and demolition debris. The disposal cell is capped with a $5-\mathrm{ft}$ (1.5-m)-thick multiple-component cover.

A 1.5-ft $(0.45-\mathrm{m})$-thick radon/infiltration barrier is placed over the contaminated materials. This barrier is constructed of onsite sandy clay. It is designed to reduce the radon-222 flux from the disposal cell to less than 20 picocuries per square meter per second and to minimize water infiltration into the tailings. A 2-ft $(0.6-\mathrm{m})$-thick layer of compacted soil lies on top of the radon/infiltration barrier to prevent adverse freeze-thaw effects to the clay barrier. A $0.5-\mathrm{ft}$ $(0.15-\mathrm{m})$-thick, coarse-grained bedding layer between the radon/infiltration barrier and the frost protection barrier provides a capillary break and promotes drainage of infiltrating water away from the radon barrier. The topslopes and sideslopes of the disposal cell are capped with rock to protect against wind and water erosion and prevent damage to the underlying radon/infiltration barrier. Due to the disposal cell's location, permanent drainage and interceptor ditches were not required at the Burro Canyon disposal site.

The erosion protection layer is $0.67-\mathrm{ft}(0.20-\mathrm{m})$-thick riprap on the topslopes and 1.0-ft $(0.3-\mathrm{m})$-thick riprap on the sideslopes. A 0.5-ft $(0.15-\mathrm{m})$-thick bedding layer between the riprap and the radon/infiltration barrier prevents damage to the barrier from rocks and loss of the fined-grained radon/infiltration barrier material. The maximum topslope grade is 4 percent with 25 percent on the sideslopes. These grades, in conjunction with the bedding layer, allow excess surface water to run off the disposal cell and be conveyed to adjacent site grades, minimizing the risk of significant erosion. The components of both the topslope and sideslope covers are designed to minimize the potential for deep percolation of precipitation into the residual radioactive material.

The riprap apron at the disposal cell toe is up to $5 \mathrm{ft}(1.5 \mathrm{~m})$ thick. At ground surface, riprap protection extends up to $20 \mathrm{ft}(6 \mathrm{~m})$ from the toe. 


\subsection{GROUND WATER PROTECTION STRATEGY}

To achieve compliance with the U.S. Environmental Protection Agency (EPA) ground water protection standards (40 CFR Part 192, Subpart A), the DOE applied supplemental standards for limited use ground water (40 CFR $\$ 192.2(\mathrm{~g})$ ). Supplemental standards are appropriate due to the low vield (less than 150 gallons [gal] per day $\left(6.6 \times 10^{-3}\right.$ liters [L] per second) in the uppermost aquifer (upper sandstone unit of the Burro Canyon Formation). Ground water in this aquifer is not a current nor potential source of drinking water because of the low yield. Pursuant to 40 CFR $\$ 192.03$, the DOE has determined that concentration limits and ground water monitoring at point of compliance (POC) wells at the Burro Canyon disposal site would not further protect human health or the environment (DOE, 1995). 


\subsection{SITE INSPECTIONS}

The DOE conducts routine inspections of the Burro Canyon disposal site to detect progressive change caused by slow-acting natural processes and to identify potential problems before extensive maintenance, repairs, or corrective action is needed. Inspections may also be performed if the DOE receives information regarding events or conditions that potentially could affect the disposal site. The DOE compares the findings from these inspections to initial baseline conditions to identify all changes over time and to provide a basis for future inspections, repairs, and corrective actions. This process is shown in Figure 3.1. Section 4.0 describes custodial maintenance and repair. Section 5.0 describes corrective action.

Site inspections are documented. After each inspection, the DOE prepares a report for the NRC that records the inspection findings and clearly identifies any adverse impacts or threats to the disposal cell.

\subsection{INSPECTION FREQUENCY}

The DOE inspects the Burro Canyon disposal site annually. The DOE may schedule more frequent inspections if necessary. The DOE will notify the NRC of the inspection schedule.

\subsection{INSPECTION TEAM}

The inspection team will consist of a minimum of two inspectors qualified to inspect disposal cell integrity and make preliminary assessments of modifying processes that could adversely affect the disposal cell.

If problems are observed that require more investigation, follow-up inspections will be performed. These inspections will include one or more technical specialists in appropriate disciplines to assess the problems under investigation. For example, a follow-up inspection by a plant specialist may be required to evaluate reports of significant plant growth on the rock cover, or a soils scientist or geomorphologist may be needed to evaluate erosion processes.

\subsection{ANNUAL INSPECTION}

Before each inspection, inspectors will perform a readiness review. The longterm surveillance program guidance (DOE, 1996a) contains information useful in preparing for inspections. 


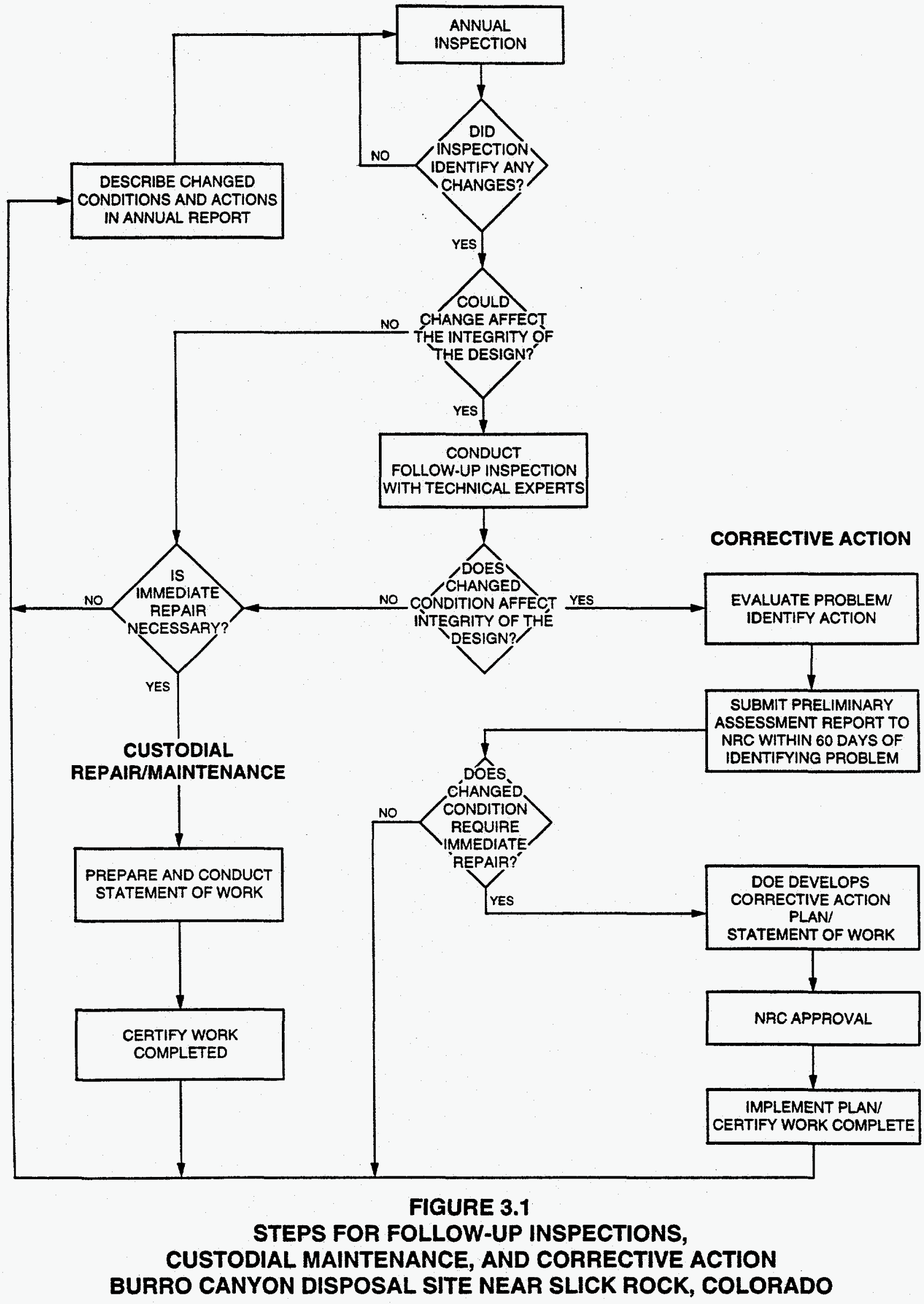


Site inspections will cover the disposal cell, the surrounding disposal site area, and the immediate offsite areas. Site inspections must be thorough enough to identify any significant changes or active modifying processes that potentially could adversely impact the disposal cell. Surveillance will be performed to identify the unanticipated effects of modifying processes such as gully formation, slope erosion, changes to the rock cover, ephemeral drainage channel changes, and significant modifications by humans, animals or plants.

Inspectors will evaluate the integrity of the disposal cell by walking a series of transects around the perimeter and over the rock cover. Sufficient transects, at approximately $150-\mathrm{ft}(46-\mathrm{m})$ intervals, will be walked to ensure that the disposal cell is thoroughly covered and inspected. Diagonal transects of the topslopes will be made and the crest line will be walked. Additional transects will be walked along the sideslopes and rock apron. Transects along the entire length of the drainage ditch will be made to determine if it is functioning as designed and can be expected to continue to function properly. Inspectors will review transect paths from previous inspections and attempt to vary the transect paths from one inspection to inspection to ensure small anomalies are not overlooked. The sample inspection checklist lists items that should be examined during inspections (DOE, 1996a).

The disposal cell has a rock cover and vegetation is not planned. However, remedial action of the areas surrounding the disposal cell included revegetation with grasses. The area surrounding the disposal cell will be monitored to determine the success of the revegetation efforts. Inspectors also will examine this area for evidence of erosion caused by wind, sheetwash, or changes in drainage patterns.

Site inspections also will monitor damage to or disturbance of permanent sitesurveillance features, fencing, gate, and locks.

From inside the disposal site, inspectors will visually survey the area within a maximum of $0.25 \mathrm{mi}(0.40 \mathrm{~km})$ from the boundary of the disposal site for evidence of land-use changes that indicate increased human activity such as new roads and paths. Inspectors will note the condition of and changes to site access roads, surrounding vegetation, and relevant geomorphic features like gullies or ephemeral drainage channels. Potential impacts to the site will be noted. The condition of offsite DOE monitor wells will be inspected until they are properly abandoned.

All site inspections will be conducted in accordance with a DOE-approved safety and health plan.

\section{$3.4 \quad$ FOLLOW-UP INSPECTIONS}

In addition to annual inspections, the DOE may conduct follow-up inspections due to unusual or annual inspection results. The DOE will monitor the disposal cell area for the occurrence of extreme natural events le.g., earthquakes, tornadoes, floods) and vandalism to ensure such events and their effects on the 
disposal cell are investigated in a timely manner. To facilitate these investigations, the DOE has requested notification from federal, state, and local agencies of discoveries or reports of any purposeful intrusion or damage at the disposal site as well as in the disposal site area. Notification agreements with the San Miguel County Sheriff's Office and the U.S. Geological Survey's National Earthquake Information Center are included in Attachment 2. The DOE will also monitor the weather for the occurrence of severe storms in the vicinity of the disposal cells. In addition, the DOE 24-hour telephone number is posted on the site entrance sign so the public can notify the DOE if problems are discovered. If an extreme natural event or vandalism has occurred, the area will be inspected to assess the damage. The notification, response, and all followup activities shall be documented. This documentation will be included in the annual site report to the NRC and become part of the permanent site file.

The nature of the occurrence and the amount of firsthand knowledge available will determine the DOE's response. If a situation poses a threat to the public, the DOE will notify individuals who may be affected and appropriate federal, state, and local agencies, including the NRC. If necessary, the DOE will schedule a follow-up inspection to assess any potential effects from the unusual occurrence, and will take any necessary response action. DOE may conduct follow-up inspections to investigate and quantify specific problems found during a previous inspection, other DOE-initiated activity, or other confirmed reports of vandalism, intrusion, damage, unusual occurrences, or other significant threat to the disposal site. Follow-up inspections will be conducted to determine whether processes currently active at or near the site threaten site security or stability and to evaluate the need for custodial maintenance, repair, or other corrective action. The scope of these follow-up inspections may be broad and similar in nature to routine site inspections or focused on specific areas of concern.

A follow-up inspection usually begins with an onsite visit by technical specialists to investigate the reported problem, determine if the disposal cell has been damaged, or determine the need for more definitive tests or studies. The DOE will schedule additional site visits if more data are needed to draw conclusions and to recommend repairs or corrective action.

\subsection{QUALITY ASSURANCE}

The DOE developed and implemented a quality assurance (QA) plan (DOE, 1992) for the site inspection program that meets the requirements of DOE Order 5700.6C. All site inspections will be conducted in accordance with this QA plan. 


\subsection{CUSTODIAL MAINTENANCE OR REPAIR}

The DOE does not plan to conduct routine maintenance at the Burro Canyon disposal site. However, the DOE will perform needed custodial maintenance or repair as determined from site inspections. The DOE will prepare a statement of work that will stipulate qualifications for the maintenance/repair contractor and will certify all custodial maintenance and repair work performed at the Burro Canyon disposal site.

The need for unscheduled custodial maintenance or repair at the Burro Canyon disposal site may be identified during an annual inspection. These repairs may include the following:

- Repairing or replacing deteriorated or vandalized warning signs, fencing, gate, locks, and monitor well caps.

- Removing volunteer plant growth from riprap-covered areas.

- Reseeding areas surrounding the disposal cell.

After the work is completed, the maintenance/repair contractor must submit verification of the completed work and/or a written report if the action is considered significant. The DOE will inspect the site, as necessary, and review the report before certifying that all work is completed in accordance with all required specifications.

The annual report to the NRC will document any repair that is performed. Copies of all records, reports, and certifications will be included in the permanent site file. 


\subsection{CORRECTIVE ACTION}

Corrective action is required when repairs are needed to address problems that may affect the integrity of the disposal cell. Site inspections are designed to identify problems at the developmental stage. Examples of conditions that might trigger corrective action are as follows:

- Surface rupture or subsidence of the disposal cell.

- Development of rills, gullies, or slope instability on the disposal cell.

- Deterioration of the erosion-protection rock on the disposal cell.

- Seepage originating from the disposal cell.

- Gully development on or immediately adjacent to disposal site property that could affect the integrity of the disposal cell.

- Damage to the cell cover or disposal site property from natural catastrophic events or vandalism.

- Evidence of hazardous material spills near monitor wells.

- Damage to the disposal cell cover from deep-rooted plant growth.

If conditions such as these are observed during an annual inspection, a follow-up inspection will be conducted. The DOE will evaluate the factors that caused the problem and identify actions to mitigate the impact and prevent recurrence by:

- Identifying the nature and extent of the problem.

- Reevaluating germane engineering design parameters.

The DOE will submit a preliminary assessment report for NRC review no more than 60 days after a problem is identified. The preliminary assessment report will evaluate the problem and recommend the next step (e.g., immediate action or continued evaluation). If the problem requires immediate repair, the DOE will develop a corrective action plan for NRC approval. Once the NRC approves the corrective action, the DOE will implement the plan. In some cases, corrective action could include temporary measures taken prior to the completion of the normal approval process. If the problem does not require immediate repair, the problem will be documented in the annual report and assessed at the next annual inspection.

NRC regulations do not stipulate a time frame for implementing corrective action. However, 40 CFR $\$ 192.04$ requires that a corrective action program begin within 18 months after an exceedance is found in established ground water concentration limits. 
The DOE does not consider assessing the extent of a problem and developing a corrective action plan to be initiation of the corrective action program.

In addition to the preliminary assessment report, the DOE may, as appropriate, prepare progress reports on each corrective action while it is under way or under evaluation.

After corrective action is complete, DOE will certify all work and submit a certification statement and supporting documentation to the NRC for review and concurrence. A copy of the certification statement will become part of the permanent site file, as will all reports, data, and documentation generated during the corrective action. 


\subsection{RECORD KEEPING AND REPORTING}

\subsection{PERMANENT SITE FILE}

The DOE will maintain a permanent site file containing site inspection reports and other supporting documentation of long-term surveillance program activities. The information placed in the site file will include:

- Documentation of disposal site performance.

- Demonstration that licensing provisions were met.

- Information needed to forecast future site-surveillance and monitoring needs.

- Reports to stakeholders regarding disposal cell integrity.

After the site is brought under the general license, the DOE will compile copies of site documentation required by the long-term surveillance program guidance for the Burro Canyon disposal site permanent site file (DOE, 1996). Copies of all deeds, custody agreements, and other property documents will be kept in the site file.

The surveillance and maintenance documentation identified in other sections of this LTSP will be maintained by the DOE and become part of the permanent site file. The DOE will update the site file as necessary after disposal site inspections, maintenance activities, or corrective actions are complete. These records will be handled in accordance with DOE directives to ensure proper handling, maintenance, and disposition. The archival procedures set forth in 41 CFR Part 101 and 36 CFR Parts 1220-1238 (Subchapter B) will be followed. All information will be available for NRC and public review.

\subsection{INSPECTION REPORTS/ANNUAL REPORTS}

Site inspection reports will be submitted to the NRC no more than 90 days after the date of the last UMTRA Project site inspection for that calendar year. If inspections are conducted annually, these submittals will be included in an annual report documenting the results of site inspections and any other activities conducted in conjunction with the long-term surveillance program. These submittals also will include reports on any follow-up inspections and custodial maintenance or repairs performed during the year.

If inspections are required more frequently than annually, site inspection reports will be submitted to the NRC no more than 90 days after the date of inspection.

If an inspection reveals any unusual damage or disruption at the disposal site, a preliminary report assessing the impact must be submitted to the NRC within 60 days. If maintenance, repair, or corrective action is warranted, the DOE will notify the NRC. The NRC will receive a copy of corrective action plans and of each corrective action progress report, or the reports will be attached to the annual report. 
The DOE will provide copies of inspection reports and other reports generated under the long-term surveillance program to the state of Colorado as required in the DOE-state cooperative agreement. 


\subsection{REFERENCES}

DOC (U.S. Department of Commerce), 1991. 1990 Census of Population and Housing: Summary Social, Economic, and Housing Characteristics, Colorado, U.S. Department of Commerce, Economics and Statistics Administration, Bureau of the Census.

DOE (U.S. Department of Energy), 1996a. Guidance for Implementing the Long-Term Surveillance Program for UMTRA Project Title / Disposal Sites, DOE/AL-62350-189, Rev. O, U.S. Department of Energy, Environmental Restoration Division, UMTRA Project Team, Albuquerque, New Mexico.

DOE (U.S. Department of Energy), 1996b. Remedial Action Plan and Site Conceptual Design for Stabilization of the Inactive Uranium Mill Tailings Site at Slick Rock, Colorado, UMTRA-DOE/AL-050508.0000, U.S. Department of Energy, Environmental Restoration Division, UMTRA Project Team, Albuquerque, New Mexico.

DOE (U.S. Department of Energy), 1995. Environmental Assessment of Remedial Action at the Slick Rock Uranium Mill Tailings Sites Near Slick Rock, Colorado, DOE/EA0376, U.S. Department of Energy, Environmental Restoration Division, UMTRA Project Team, Albuquerque, New Mexico.

DOE (U.S. Department of Energv), 1992. Long-Term Surveillance and Maintenance Program Quality Assurance Program Plan, P-GJPO-152, prepared by Chem Nuclear Geotech, Inc., for the DOE Grand Junction Projects Office, Grand Junction, Colorado.

Merritt, R. C., 1971. The Extractive Metallurgy of Uranium, Colorado School of Mines Research Institute, Golden, Colorado.

MK-ECE (Morrison Knudsen Corporation - Engineering, Construction, \& Environmental Groupl, 1996. UMTRA Project, Slick Rock, Colorado, Surveillance and Maintenance Subcontract Documents - Final Design for Review, prepared by MK-ECE for the U.S. Department of Energy, Environmental Restoration Division, UMTRA Project Team, Albuquerque, New Mexico.

MK-F (MK-Ferguson), 1997. Slick Rock, Colorado, Final Completion Report, prepared by MK-F for the U.S. Department of Energy, Environmental Restoration Division, UMTRA Project Team, Albuquerque, New Mexico.

\section{CODE OF FEDERAL REGULATIONS}

10 CFR Part 40, Domestic Licensing of Source Material, U.S. Nuclear Regulatory Commission.

36 CFR Parts 1220-1238, National Archives and Records, Subchapter B - Records Management, National Archives and Records Administration. 
36 CFR Parts 1220-1238, National Archives and Records, Subchapter B - Records Management, National Archives and Records Administration.

40 CFR Part 192, Health and Environmental Protection Standards for Uranium and Thorium Mill Tailings, U.S. Environmental Protection Agency.

41 CFR Part 101, Federal Property Management Regulations, General Services Administration.

\section{DOE ORDERS}

Order 5700.6C, Quality Assurance, 21 August 1991, U.S. Department of Energy, Washington, D.C.

\section{UNITED STATES CODE}

42 USC $\$ 7901$ et seq., Uranium Mill Tailings Radiation Control Act of 1978, 8 November 1978. 
ATTACHMENT 1

NRC CONCURRENCE DOCUMENTATION 
(TO BE PROVIDED WHEN RECEIVED) 
ATTACHMENT 2

SITE REAL ESTATE INFORMATION 


\section{REAL ESTATE DOCUMENTATION}

\section{INTRODUCTION}

Remedial action at the Slick Rock, Colorado, Uranium Mill Tailings Remedial Action (UMTRA) Project site consisted of relocating the contaminated materials from two former mill processing sites near Slick Rock to the Burro Canyon disposal site.

\section{JURISDICTIONAL TRANSFER OF THE DISPOSAL SITE}

The disposal site is located on public land administered by the U.S. Department of the Interior (DOI) Bureau of Land Management (BLM). Under the requirements of the Uranium Mill Tailings Radiation Control Act (UMTRCA), as amended, the U.S. Department of Energy (DOE) acquired the disposal site land via a public land order (PLO). The PLO permanently transferred 61.25 ac (24.8 ha) from the public domain in San Miguel County, Colorado. Publication in the Federal Register (Vol. 60, No. 88, 21984, FR Doc. 95-10992) of PLO 7138 established the effective date of the transfer as 4 May 1995. As a result of the transfer, the land is no longer subject to the operation of the general land laws, including mining and mineral leasing laws. Transfer of the land to the DOE vested in the DOE the full management, jurisdiction, responsibility, and liability for the land and all activities conducted thereon, except that the DOI, through the BLM, retained the authority to administer any claims, rights, and interests in the land established before the effective date of the transfer.

\section{LEGAL DESCRIPTION}

The legal description in the PLO describes the disposal site area as follows:

Township 44 North, Range 18 West, New Mexico Principal Meridian. Section 21: S1/2 S1/2 SE1/4 SW1/4; Section 28: NE1/4 NW1/4, N1/2 NE1/4 SE1/4 NW1/4, N1/2 S1/2 NE1/4 SE1/4 NW1/4, NE1/4 NW1/4 SE1/4 NW1/4, and N1/2 SE1/4 NW1/4 SE1/4 NW1/4. The area described contains approximately 61.25 ac (24.79 ha) of public land in San Miguel County, Colorado.

\section{REPOSITORY}

Real estate correspondence and related documents are maintained and filed by the Property Management Branch, Property and Administrative Services Division, Albuquerque Operations Office, P.O. Box 5400, Albuquerque, NM 87115, 505-845-5598.

\section{References}

42 USC $\$ 7901$ et seq., Uranium Mill Tailings Radiation Control Act of 1978, 8 November 1978. 
ATTACHMENT 3

AGENCY NOTIFICATION AGREEMENTS 
Mr. Bill Masters,

\author{
Department of Energy \\ Albuquerque Operations Office \\ P.O. Box 5400 \\ Albuquerque, New Mexico 87185-5400
}

NoV 18

San Miguel County Sheriff

P.O. Box 455

Telluride, CO 81435

Dear Sheriff Masters:

The U.S. Department of Energy (DOE) Uranium Mill Tailings Remedial Action Project is requesting notification in the event of any unusual activities or events in western San Miguel County at the Burro Canyon disposal cell. The disposal cell is east of Slick Rock and can be reached by going east on SH-141 from Slick Rock, and north onto CR-T11 to the disposal site. A map to the site is enclosed.

The purpose of the notification request is to assist the DOE in monitoring and maintaining the integrity of the Burro County disposal site and to ensure public safety.

If, during the course of routine activities, anything out of the ordinary that could potentially impact the site is observed by your staff or reported to your office, we would appreciate notification to the DOE Grand Junction Projects Office's 24-hour phone line at (970) 248-6070.

If the notification request discussed above is agreeable to you, please sign and retum the attached reply letter for our records as soon as possible.

Should you have any questions, please contact me at (505) 845-4030. Thank you for your attention in this matter.

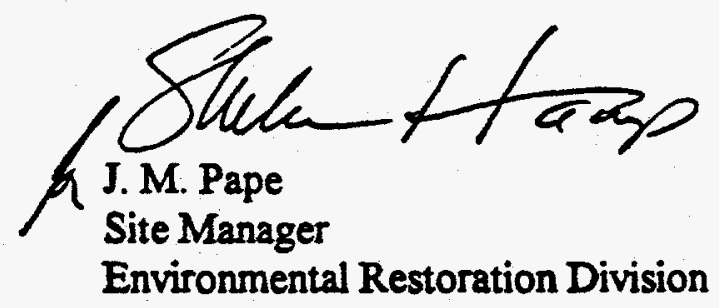

Enclosures

ccw/o enclosures

J. Virgona, GPO

S. Hamp, ERD

C. Jones, MACTEC-ERS

M. Gawthrop, TAC

W. Migdal, TAC 
National Earthquake Information Center. World Data Center A for Seisziology

Dimer

cas) 236re

cemeres

(com) seretes

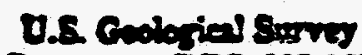

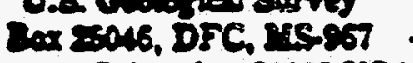

Defver, Colardo mes USA

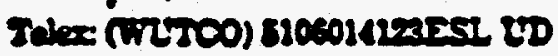

:

Qperations

(c03) 236-2800

QED

$000) 328.2663$

Clintos C. Straghte

$-2$

We brve estered the folioring selection criteris into our notifiesion progrem:

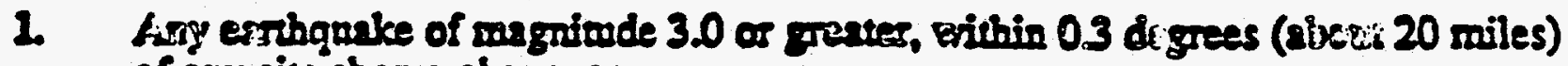
ef any gite itown above, or

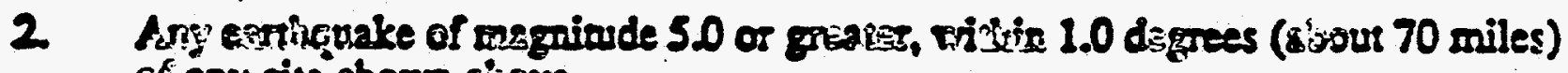
6. eny aite shown rivive.

Sineerely,

Smaen wo Dengere

Erive Presgrave

U.S. Ceologieal Survey

Nabiorsel Eartbqiake lno formanion Center

P.O. $86 \times 250146$

Mail Sto 66 ?

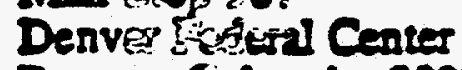

Denves: Colondo 80225

Pleare address Future comespondaree to sthert Koyengi at the aboos address. I have monod to a different poject.

Throuk you + best regands,

Eruce Prengere

A3-3 